\title{
Kolektif Anlatı ve Vatandaşlık Kimliğinin İnşasına Dair Sorular, Cevaplar ve Yeni Sorular
}

\author{
Meral Uğur Çınar
}

yardımcı doçent, bilkent üniversitesi, siyaset bilimi ve kamu yönetimi bölümü meral.ugur@bilkent.edu.tr

\section{Abstract \\ Collective Memory and National Identity: Questions, Answers and New Questions}

The article evaluates the current state of the literature on the collective memory-national identity nexus. Pointing at the interaction between state and non-state actors in the formation and reproduction of collective memory and national identity, the article shows both collective memory's unifying and divisive role. By pointing at the unintended consequences of institutionalized collective memories on citizenship policies and by showing how transnational dynamics affect the collective memory-national identity link, the article invites further research in the field that is comparative, multifaceted, interdisciplinary and nonfunctionalist. By showing collective memory's effect on institutional design, the article also urges for bodies of literature that have hitherto neglected collective memory to take this phenomenon seriously in their analyses of institutional design. The article also calls for studies that analyze the implications of changing communicative technologies for the link between collective memory and collective forms of identity.

keywords: collective memory, historical narratives, national identity, citizenship policies, institutional design 


\section{Résumé}

\section{Mémoire collective et identité nationale: questions, réponses et nouvelles questions}

Cet article prend pour objet l'état actuel de la littérature sur le lien entre la mémoire collective et l'identité nationale. En soulignant l'interaction entre acteurs étatiques et non étatiques dans la formation et la reproduction de la mémoire collective et de l'identité nationale, l'article montre à la fois le rôle unificateur et divisif de la mémoire collective. En soulignant les conséquences imprévues des mémoires collectives institutionnalisées sur les politiques de la citoyenneté et en montrant comment la dynamique transnationale affecte le lien entre la mémoire collective et l'identité nationale; l'article fait appel à des nouvelles recherches comparatives, multidimensionnelles, interdisciplinaires et non-fonctionnalistes dans le domaine. En montrant l'effet de la mémoire collective sur le design institutionnel, l'article exhorte également les corps de littérature qui ont jusquelà négligé la mémoire collective à prendre ce phénomène au sérieux dans leurs analyses du design institutionnel. L'article demande également des études qui analysent les implications de l'évolution des technologies de communication pour le lien entre la mémoire collective et les formes d'identité collectives.

mots-clés : mémoire collective, récits historiques, identité nationale, politiques de citoyenneté, design institutionnel

\section{Öz}

Bu makale, kolektif hafıza ile ulusal kimlik ilişkine dair literatürü değerlendirmekte ve bu ilişkinin daha belirgin şekilde, çok boyutlu ve karşılaştırmalı olarak çalışılması gerektiğini vurgulamaktadır. Makale, ulus inşa sürecinde kolektif hafızayı devletin ve çeşitli toplulukların etkileşiminden beslenen bir olgu olarak görmektedir. Dolayısıyla, kolektif hafıza ortak toplumsal payda oluşturabildiği gibi siyasal çatışmalarda merkezi rol de oynayabilmektedir. Çalışmada, kolektif hafızanın öngörülemeyen ve işlevselcilikle açıklanamayan yanları, ulus-devlet sınırlarını aşan dinamikleri ve interdisipliner boyutu da ortaya konulmaktadır. Makale kolektif hafızanın ulusal kimlik üzerindeki etkisini sadece vatandaşlık politikaları ve ders kitaplarında ya da anıtlarda değil, aynı zamanda kimliklerin yeniden üretilmesini sağlayacak kurumsal yapıların dizaynında da aramamı gerektiği belirterek bugüne dek kolektif hafızaya gerekli önemi vermemiş literatür gruplarının da ilgisini bu alana çekme amacı taşımaktadır. iletişim teknolojilerindeki dönüşümün kolektif hafıza ve kolektif kimlik arasındaki ilişkiye olan etkisinin yeni çalışmalara alan açtığı gerçeği de makalenin sonucunda tespit edilmektedir.

anahtar kelimeler: kolektif hafiza, tarihsel anlatılar, ulusal kimlik, vatandaşlık politikaları, kurumsal dizayn 


\section{Giriş}

Modern ulus-devlet çağında "homojenliğini ve otantikliğini" ortaya koymak amacıyla ülkeler bugünlerini ve geleceklerini kurmaya, geçmişlerini kurarak başlamışlardır. Siyasal girişimciler, ulusal kimliklerini geçmişle süreklilik kurarak meşrulaştırmak istemişlerdir. Bu sebeple, sosyal bilimciler de giderek tarihi, geçmişi anlamanın nesnel bir aracı olarak ele almanın ötesinde, onun yazılış biçiminin içinde yaşadığımız dünyaya yansımalarını da irdelemeye başlamışlardır. Böylece, kolektif hafıza çalışmaları başlı başına bir literatür oluşturmuş duruma gelmiştir. Var olan bu literatürün üzerine kurarak çok önemli katkılar yapmak mümkün olacaktır. Bu makalede, hem kolektif hafıza ve kolektif kimliklerin oluşumu arasındaki iliş̧kiye dair literatürün bir değerlendirmesi yapılacak, hem de bu alanda şimdiye dek sorulmuş önemli sorular ve gelecekte sorulması yararlı temel sorular ortaya konacaktır.

Makale ilk olarak kolektif hafızanın kișisel hafıza ve tarih ile ilişkisini tartışmakta, ardından kolektif hafızanın kişiden kişiye ve nesilden nesile aktarılışında etkin olan mekanizmaları incelemektedir. Yeni iletişim yöntemlerinin ve teknolojilerinin yaygınlaşması her ne kadar küresel kolektif hatırlama biçimlerinin gelişmesine kapı aralasa da günümüzde kolektif hafıza, kolektif aidiyetler arasında halen en çok ulus devlet ile olan yakınlığını korumaktadır. Bu sebeple, makale geri kalan kısmında kolektif hafıza ve ulusal aidiyet arasındaki ilişkiye yoğunlaşmakta ve bu alandaki literatürün bir değerlendirmesini sunmaktadır. Makale, kolektif hafıza ve vatandaşlık politikaları arasındaki ilişkiyi irdeledikten sonra ulusal kimliğe ilişkin temel siyasal kurumların geliştirilmesinde kolektif hafızanın rolünü incelemektedir. Mevcut literatürdeki eksikliği vurgulayan makale, bu tarz kurumların oluşmasında ve devamlılığında kolektif hafızanın oynadığı rolün altını çizmektedir. Bu kısımdan sonra makale, kolektif hafıza ve kimlik inşası arasındaki ilişkinin incelemesiyle ortaya çıkan önemli bulgulara dikkat çekmektedir. Bunlar, baskın ve madun kolektif hafıza anlatıları arasındaki etkileşim, kolektif hafızanın ulusal kimlik üzerinde öngörülemeyen etkileri ile sınır ötesi dinamiklerin kolektif hafıza ve ulusal kimlik üzerine etkileri şeklinde sıralanabilir. Makalenin sonuç bölümü, bulguları tartışmakta ve yorumlamaktadır. Sonuç olarak, karşılaştırmalı ve interdisipliner çalışmaların gerekliliği ortaya konurken bir bağımsız değişken olarak, yani sadece belirlenen değil, belirleyen olarak kolektif hafızanın da çalışmalarda kendine daha çok yer bulması gerektiği sonucuna varılmaktadır. Bu şekilde kolektif hafıza ve kimlik inşa dinamiklerinin çok daha iyi anlaşılacağı öngörülmektedir.

\section{Kolektif Hafıza}

Kolektif hafızanın toplumsal kimliklerin oluşmasında, korunmasında ve tartışılmasında ne gibi bir rol üstlendiğine bakmadan önce kavramın kendisine açıklık getirmek yerinde olacaktır. Bu açıdan Halbwachs'ın (1980) artık klasikleşen çalışması bize ışık tutmaktadır. Bir anlamda kolektif hafıza çalışmalarının 
kurucusu olarak nitelendirebileceğimiz Halbwachs, aslında en bireysel görünen hatırlamaların bile kolektif olduğunu iddia etmiştir. Zira diğer insanlar, fiziksel olarak var olmasalar dahi hatılamamı üzerinde etki sahibidirler. Halbwachs'a (1980, s. 23) göre bunun sebebi hatıralarımızı başkaları vasıtasıyla hatırlıyor oluşumuzdur. Hatırladıklarımızda başka insanlardan parçalar bulunur. İçinde bulunduğu gruptan koparımış haldeyken insanların geçmişi tutarlı bir bütün olarak hatırlamalarına imkân yoktur. Halbwachs (1980, s. 35) çocukluk anıları örneğini de bunun için vermektedir. Zira insanlar çocukluk hikâyelerini kayıt altına alırken anne-babalarının anlatılarından da faydalanmaktadırlar.

Her ne kadar en kişisel hatırlamalar dahi kolektif dinamiklerle şekillenmiş olsalar da, kişilerin kendi geçmişlerine dair hatırladıkları ile kolektif düzeyde grup olarak hatırladıkları arasında nitel farklııklar mevcuttur. Bu sebeple, Kansteiner (2002) ve Olick (1999) gibi araştırmacılar bireysel ve kolektif hafızanın gerek analitik olarak, gerekse de metodolojik olarak birbirinden ayrılması gerektiğini düşünmektedirler. Bu noktada Kansteiner toplanmış (collected) ve kolektif (collective) hafıza arasında da bir ayrım yapmaktadır. Ona göre toplanmış hafıza, tek tek bireylerin hafıza deneyimlerinin toplamından meydana geldiği için psikolojik metotlarla çalışılabilir. Ancak kolektif hafızanın kendi dinamikleri vardır. Örneğin, kolektif travma konusunun kolektif hafızanın toplumsal dinamikleri çerçevesinde çalışılması gerekmektedir. Olick de yine aynı ayrıma dikkat çekmektedir. Ona göre de toplum içinde şekillenmiş kişisel hafıza ile sui generis kolektif bir olgu olarak hafıza arasında bir ayrım yapmamız gerekmektedir.

Assmann (2008) da hatıralar arasında bir boyut ayrımı yapma gereği duyar. Ona göre iletişimsel (communicative) ve kültürel (cultural) hafıza arasında ayrım yapmak gerekmektedir. İletişimsel hafıza, Halbwachs'ın da daha çok üzerinde durduğu, gündelik iletişimleri, resmi olmayan ve kurumsallaşmamış hafızayı temsil ederken, kültürel hafıza kurumsallaşmış, özelleşmiş ve biçimlenmiş/ biçimlendirilmiş hafızaya karşılık gelmektedir. Birincisi daha akışkan ve zaman olarak daha kısıtlıyken, ikincisi daha stabil ve uzun solukludur.

Geffrey White (1999) kişisel hafıza ile ulusal tarih arasındaki bağlantıyı inceleyerek kişisel hafıza ve kolektif hafıza arasındaki ilişkiye dair çözümlemelerde bulunmuştur. White'a göre kişisel olan ile kolektif olan iki ayrı hikâye olmaktan ziyade birbiriyle iç içe geçmiş durumdadırlar. White'ın bulgularına göre, bu iki seviyeden hafıza anlatısı arasındaki bağlantılar şu şekilde sağlanmaktadır (1999, s. 507). Illk olarak, "ben" ve "biz" kişi zamirleri ve bunlara benzer başka semboller kişisel ve toplumsal olanı birbirine bağlamak için kullanılmaktadır. Ikinci olarak da kişisel hikâyeler ulusal hikâyeleri kendine dahil edecek ve duygusallaştıracak şekilde alegorik olarak kullanılmaktadır.

Kolektif hafıza, bir akademik disiplin olarak tarihten hem ayrışmakta hem de onunla yakın bir etkileşime girmektedir. Önceleri tarih ve kolektif hafıza arasında çok keskin bir ayrım olduğu varsayılmıştır. Örneğin Halbwachs (1980, 
s. 78) kolektif hafızanın yaşayan gruplarla ve geleneklerle alakalı olduğunu ve kolektif hafızanın birden çok versiyonunun bulunabileceğini söylemiştir. Öte yandan, ona göre tarih gruplar üstü ve gruplar dışıdır. Tek bir tarih vardır ve tarihçi objektif olmak durumundadır. Aynı şekilde Nora da (1989, s. 7) gerçek hafıza ve tarih arasında bir ayrım yapmaktadır. Onun analizi ise Halbwachs'tan biraz farklılaşmaktadır. Ona göre gerçek hafıza topluluklara aittir ve ancak müdahale edilmemiş, bozulmamış "ilkel düzeyde arkaik" topluluklarda bulunur. Tarih ise geçmişi organize eder ve bu hususta evrensel bir otoriteye sahip olduğunu iddia eder. Modern toplumlarda bu hafızadan bu kadar çok bahsedilmesinin nedeni de Nora'ya göre (1989, s. 7) aslında gerçek manada kolektif hafıza namına pek bir şey kalmamış olmasındandır.

Hayden White (1978, s. 99) aslında tarih ve kolektif hafıza arasındaki ayrımın gerçekte o kadar katı olmadığını ortaya koyar. Söylediği gibi, tarihin de edebi bir yönü vardır. Elbette gerçek tarihçi ile şarlatanlar arasında ayrım yapmak mümkündür ancak disipliner kurallara en sadık tarihçi bile geçmişte yaşanan olayları bir olay örgüsü içerisine dizer ve onları o şekilde anlamlandırır. Bu anlam örgüsünde önceden belirlenmiş bir kalıp ya da tek bir doğru dizilim yoktur. Tarihin edebi çalışmalara yaklaşması da bu yöndendir. White'ın tespitleri akademik tarihçilik için yapılmıştır. Ancak konu resmi tarih olunca tarih ve kolektif hafıza arasındaki ayrım da giderek bulanıklaşmaktadır.

White'ın tarihin edebi yönüne ve anlatılar üzerine inşa edilmiş olduğu gerçeğine yapmış olduğu vurgu kolektif hafıza çalışmaları açısından oldukça önemlidir. Zira kolektif hafıza kendiliğinden var olan ve grup içerisinde nesilden nesile taşınan bir olgu değildir. Kolektif hafıza çeşitli iletişim yöntemleri ile topluluk arasında ve zaman içinde yayılır.

Kolektif hafızanın yayılmasında en önemli rol üstlenen etmenlerden biri tarihsel anlatılardır. Siyasal düşünceler gibi geçmiş de anlatılar yolu ile aktarıır. Burada anlatılardan kasıt, yaşanan olayların birbirinden bağımsız olaylar olarak ele alınmasındansa bir öykü halinde birbirine bağlanmasıdır. Ricoeur (1980), Maclntyre (2007), Taylor (1989) ve Bruner (1991) gibi düşünürlerin de belirttiği üzere, insanlar sosyal olguları anlatı şeklinde anlar, değerlendirir ve iletirler. Daha da ötesi, toplumsal ve siyasal kimlikler anlatılar yoluyla inşa edilir (Somers, 1994; Smith, 2003). Buradan anlatıların kolektif hafıza bağlamında oynadığı rol hususunda önemli çıkarımlarda bulunabiliriz. Anlatılar, geçmişe dair birbirinden bağımsız gibi görünen imge ve olaylar etrafında bir anlam örgüsü kurarlar. Böylece geçmişle alakalı algıların aktarımasını sağlarlar. Brockmeier'in (2002) söylediği gibi, "Eğer sadece kutuda topladığım fotoğrafları ve bu fotoğraftakilerin isimlerini saymakla kalmayıp bunların benim için ne anlama geldiğini de ifade edeceksem, anlatılar bu ifadenin merkezinde yer alacaktır."

Her anlatı aynı ölçüde başarılı değildir. Bunun en iyi örneğini Davis, Irak üzerine yapmış olduğu kapsamlı çalışma ile veriyor. Irak'ta tarihsel olarak 
farklı ulus inşa projelerini karşılaştıran Davis (2005), "Irakçı" (Iraqist) bir ulus vizyonunun Pan-Arabist anlayışa göre daha demokratik, katılımcı ve istikrarlı olmuş olacağını ifade ediyor. Ancak Irakçı seçeneğin başarıı olamamasını ve Pan-Arabist seçeneğin galip gelmesini de her iki grup arasında tarihten gelen güç orantısızığı kadar, Pan-Arabist kampın tarihsel hafızayı daha iyi mobilize edebilmesine ve topluma daha çok hitap edebilen tarihsel anlatılar kurabilmesine bağlıyor.

Elbette ki anlatılar dışında başka iletişim yolları kanalıyla da kolektif hafıza aktarılmaktadır. Örnek olarak, Connerton (1989, s. 102) aslında hafıza ve geleneğin metinsel olmayan (non-textual) ve bilinç dışı (non-cognitive) yollarla da taşındığını savunmaktadır. Connerton'a göre kolektif hafıza metinsel yollarla aktarıldığı kadar bedensel pratiklerle de aktarılmaktadır. Bu pratikler içerisinde duruş ve jestlerin yanı sıra yeme-içmedeki görgü kurallarını da saymak mümkündür. Bir başka kolektif hafıza taşıyıcı olarak jenerasyonları sayabiliriz. Elbette burada jenerasyonlar arası hafıza geçişini peşinen kabul etmektense problematize etmemiz gerekir. Zira bir grubun şahsen tanık olduğu anılar, ilerleyen nesillere geçerken farklı bir süreç izlerler. Bu konuyu başarıyla ele almış bir çalışma için Marianne Hirsch'e (2008) bakılabilir. Hirsch post-hafıza (postmemory) kavramını geliştirerek tarihsel ve kolektif travmaları bizzat yaşamış olanların ailelerinde onlardan sonra gelenlerin deneyimlediği hafızayı çözümlemeye çalışır. Ona göre bu olaylar aktarılırken bir hatırlamadan ziyade yaratııı bir süreç söz konusudur. Burada özellikle annelik üzerinden kurulan troplara, yani figüratif kalıplara, dikkat çeken Hirsch bu yöndeki tartışmasında feminist teorileri de kolektif hafıza çalışmalarına başarıyla yediriyor. "Annenin kaybı" gibi troplar Hirsch'e göre post-hafızanın kurulmasında çok önemlidir çünkü bu kalıplar, geçmişle gelecek arasında köprüler kurmaktadır. Böylesi kalıplardan faydalanılmasında fotoğraflardaki imgeler de önemli bir rol tutar. Böylece travmatik olaylar yaşanırken fiziken orada olmayanlar, bu imgeler üzerinden kurdukları anlatı kalıplarıyla önceki jenerasyonların hafızalarına bağlanırlar.

Kolektif hafızanın aktarıması söz konusu olunca medyayı da ele almadan geçmek mümkün değildir. Nitekim kolektif hafıza literatürü de bu konuya eğilmiş bulunuyor. Burada öne çıkan konulardan bir tanesi medyanın bir olayın kolektif hafızada ön plana çıkmasında ve belli biçimde şekillenmesinde oynadığı roldür. Bu hususta, örneğin, Yoram Peri, İsrail başbakanı Yitzhak Rabin'in suikastını incelemektedir. Bulguları ışı̆ında Peri (1999), medyanın özellikle de televizyonun, kolektif hafıza ile arasında simbiyotik bir ilişsi geliştirdiğini iddia etmektedir. Buna göre, medya, seremoniler kanalıyla arzu edilen toplumsal birlik ve dayanışma tablosuna katkı sağlarken, aynı zamanda da bu süreçte hatırlamanın vuku bulduğu yer olarak meşruiyetini artırmaktadır.

Son olarak, yeni sinema teknolojilerinin hafızanın aktarılmasındaki rolüne bakmak faydalı olacaktır. Landsberg de bu konuda yaptığı çalışmayla yeni araştırma kulvarları açmış görünüyor. Protez hafızadan (prosthetic memory) 
bahseden Landsberg (2003), televizyon ve sinemanın, henüz tam olarak anlamadığımıı iddia ettiği şekillerde daha empatik ve dayanışmacı bir siyasal iklimin yaratılmasında oynayabileceği rol üzerinde duruyor. Yeni kamera teknikleri, çekim açıları ve yönetmenlik yaklaşımlarıyla artık izleyicinin de kendisini hikâyede anlatılan kolektif hafıza unsurunun içinde hissedebildiğini ve olayları neredeyse kahramanın gözünden deneyimleyebildiğini söyleyen Landsberg, buna örnek olarak ünlü Piyanist filmini gösteriyor. Piyanist filminde çekim teknolojileri sayesinde izleyici pek çok defa olaylara kahramanın gözünden ve açısından dâhil oluyor. Bu da Landsberg'e göre yeni bir kamusal kültürel hafıza yaratarak daha evrensel ve toplumsal sorumluluk hissine dayalı bir hafızanın gelişmesine katkı sağlayacaktır. Landsberg bu hafızaya prostetik adını vermektedir. Zira hafıza kişinin kendisine ait olmasa da tıpkı bir protez organ gibi kişinin kendisine dahil olmaktadır.

Bu noktadan hareketle şunu da sorabiliriz: Küresel bir hafıza mümkün müdür? Errl'in (2011, s. 8) iddia ettiği gibi, ulus-devletler giderek küresel medya kültürlerinin ve diasporik kamusal alanların etkisi altında kolektif hafızanın temel belirleyicisi olma özelliklerini yitirip daha akışkan bir hafıza anlayışına mı yerlerini bırakmaktadırlar? Levy ve Sznaider (2002) bu konuda umutludur. Bir kozmopolit hafızanın gelişebileceğine örnek olarak da Yahudi soykırımının ve bunun tekrarlanmaması gerektiği konusundaki kararlıığın dünyada nasıl bir ahlaki mihenk taşı haline geldiğini vermektedirler. Poole (2010) ise bu önermelere kesin olarak karşı çıkmaktadır. Ona göre aslında kozmopolit hafıza olarak sunulan şey bir kitsch'ten ibarettir. Yani gerçekte olan, pazarlanmaya elverişli yüzeysel duyguların kolektif hafızanın ucuz birer kopyası olarak dolaşıma sunulmasıdır. Bu açıdan Poole'nin argümanı hem Levy ve Sznair'e hem de Landsberg'e bir karşı argüman olarak ele alınabilir.

Her ne kadar küresel bir hafızanın ve kozmopolit bir kimlik anlayışının oluşması sıkça tartışılagelen konular halini almış olsa da, bugün için halen kolektif hafıza organik bir bağ olarak en sıkı ilişkisini ulus-devlet ile kurmuş görünmektedir. Bu nedenle de makalenin geri kalan kısmı ağılıklı olarak kolektif hafıza ile ulusal kimlik politikaları arasındaki ilişkiye eğilecektir.

\section{Kolektif Hafıza ve Ulusal Kimlik}

Devletlerce kurumsallaştııımış tarih yazımının ve topluluklarda hâkim olan tarih algısının vatandaşlık, kimlik ve çoğulculuk üzerinde önemli etkisi vardır. Buna rağmen, mevcut literatür tarih anlatımı ve vatandaşlık ilişkisini yeterli derecede ele almamaktadır. Tuhaftır ki insanlar ulusal kimlik anlayışlarını tarihsel anlatılar yoluyla ediniyorken, siyasal dinamiklerin incelenmesinde tarihsel anlatıların rolü göz ardı edilmektedir. İstisnai çalışmalardan birinin sahibi olan David Art'ın (2006, s. 17-18) da ifade ettiği gibi, sorulsa pek çok siyaset bilimci kolektif hafızanın önemli olduğunu kabul edecekken, geçmiş hakkındaki düşünceler ile siyasal güç arasındaki bağlantıyı araştıran çalışma sayısı oldukça azdır. Buna ek olarak, 
pek çok kolektif hafıza uzmanı bu hafızaların nasıl oluştuğuna bakarken kolektif hafızanın toplumsal ve siyasal hayat üzerine etkisine bakan çalışmalar hala yine çok azdır. Benzer şekilde, yine önemli kolektif hafıza araştırmacılarından olan Kansteiner (2002, s. 184) da aradaki bağlantı çok net olmasına rağmen, hafıza ve kimlik ilişkisinin kolektif hafıza çalışmalarında yeterince ele alınmamasından yakınmaktadır. Son olarak, yine alanlarında öncü çalışmalara imza atmış olan Roediger ve Wertsch (2008, s. 14) de "geçmişten alınan dersler"in siyasal düşünce ve kararları etkilemekteki gücü konusunda keşfedilmeyi bekleyen çok şey bulunduğunu belirtmektedirler.

Illerleyen sayfalarda daha ayrıntılı olarak tartışılacağı gibi, aslında bu kopukluk iki yönlüdür. Milliyetçilik çalışmaları kolektif hafızanın önemini kabul ederken, bunun vatandaşlık politikaları üzerindeki somut etkisini ortaya koymamakta ve konuya karşılaştırmalı olarak eğilmemektedir. Öte yandan, vatandaşık literatürü de tarihsel olayların önemini (örneğin, bir ülkede devletin mi önce kurulduğu, millet fikrinin mi önce ortaya atıldığı gibi hususlar) araştııırken bu tarihin nasıl yorumlandığının da tarihin kendi süreci kadar önemli olduğu gerçeğini göz ardı etmektedir.

Illk kısmı daha ayrıntılı açıklayacak olursak, kolektif hafızanın vatandaşlık ve kimlik politikaları üzerindeki etkisini anlamak için çoğu zaman karşılaştırmalı bir bakış açısı ve anlatılardaki farklııklara karşı duyarlııı gerekmektedir. Şu ana kadar ulus inşa süreçlerinde ve milliyetçi ideolojide tarih anlatımın rolünü kabul eden çalışmaların pek çoğu bu tarihsel anlatıların bir tipolojisini çıkarmaya ve hangi tür anlatıların ne tür vatandaşlık ve kimlik politikaları için kolaylaştırııı rol oynadıklarına bakmamışlardır.

Bildiğimiz klasik çalışmaların üzerinden şöyle genel hatlarıyla gitmek bile bu tespitin haklıı̆ını ortaya koyacaktır. Örneğin, Benedict Anderson (1991) milliyetçi seçkinlerin tarih anlatımı yoluyla geçmiş ve şimdiki jenerasyonları nasıl birbirlerine bağladıkları ve bu şekilde bugüne anlam kattıklarını bize çok güzel anlatıyor. Bu analizi ilerletmek için tarihsel anlatıları sınıflandırabilir ve hangi türden anlatıların ne tür vatandaşlık politikalarına karşlık geldiğini tespit etmeye çalışabiliriz. Buradaki tespit Hobsbawm ve Ranger'ın (1983) The Invention of Tradition kitabı için de geçerlidir. Bu kitap anma stratejilerinin 19. yüzyıl sonu Avrupa siyasetçileri tarafından stratejik olarak nasıl kullanıldığını, bu siyasetçilerin yapay geleneklerle ulus-devletin prestij ve otoritelerini nasıl güçlendirdiklerini anlatmaktadır. Bunun sonucunda değişik ülkelerde bu stratejilerin nasıl kullanıldıklarını öğrensek de kitap, genel hatlarıyla, değişik vakaların bir derlemesi olarak kalmanın ötesinde bize sistematik bir karşılaştırma sunmuyor (Benzer örnekler için bknz. Gillis, 1994; Berger, Donovan ve Passmore, 1999).

Milliyetçilik çalışmaları kadar kolektif hafıza çalışmaları da çoğu zaman fazla dar ve izole bir çerçevede sürdürülmektedir. Pek çok kolektif hafıza çalışması tek bir vakaya ayrıntılı olarak bakarken, bu vakadan ulus ve kimlik inşasına dair daha 
geniş teorik literatüre fazlaca bir katkı sunmamaktadırlar (Benzer eleştiriler için bknz. Olick, 2003, s. 4; Zerubavel, 2003, s. 10). Türkiye özelinde bakılacak olursa, kolektif hafıza üzerine hatırı sayııı bir yazın oluşmuş durumdadır (Bu konuda yazılmış önemli derleme eserler için bknz. Özyürek, 2007a; Neyzi, 2011; Cantek ve Orhon, 2014). Ancak bu çalışmalar ya ulusal ya da bölgesel düzeyde Türkiye'ye odaklanmakta, Türkiye'yi başka ülkelerle karşılaştırmalı olarak incelememektedir. Olick (1998, s. 134) ve Art'ın (2006) da belirttiği gibi, kolektif hafıza genelde daha çok bir bağımlı değişken olarak ele alınmış ve bir bağımsız değişken olarak başka siyasal ve toplumsal olgulara, özellikle de ulusal kimlik formasyonuna yarattığı etki doğrudan ele alınmamıştır.

Çalışmaları bu noktada bırakmak bizi birtakım önemli araştırma programları oluşturmaktan alıkoyuyor. Zira her ulustaki inşa edici siyasal seçkin grubu tarihsel anlatılardan faydalanıyor olsa da farklı gruplar farklı hikaye kalıpları ortaya koymakta ve bu kalıpları (okullar, müzeler, kitaplar vs. yoluyla) kurumsallaştırmaktadırlar. Assmann'ın (1992, s. 14) da belirttiği gibi topluluklar çok farklı biçimlerde birer hatırlama kültürü geliştirirler. Bu farklı anlatı kalıpları da farkı ulusal kimliklerin inşasına yol açmaktadırlar. Aynı şekilde, kurumsallaşmış ulusal kimlikler de birbirinden farklılık göstermektedirler. Bu noktadan hareketle, vakalar arası karşılaştırmalar yapılarak bu alanda benzerlikler ve farklılıklar daha sistematik bir biçimde ortaya konabilir ve böylelikle alana ilişkin literatür daha birikimli ve etkileşimli olarak ilerleyebilir.

Olayın diğer tarafına dönecek olursak, yukarıda da belirtildiği gibi vatandaşık literatürü de tarihsel olayların vatandaşlık politikaları üzerindeki rolünü araştıırken bu tarihin nasıl yorumlandığının da tarihin kendi süreci kadar önemli olduğu gerçeğine eğilmemiştir. Anthony Smith'in (1994, s. 18) de ifade ettiği gibi "belki de milliyetçiliği anlamaktaki temel soru geçmişin geleceğin şekillenmesinde oynadığı roldür." Bu ifade doğru olmakla birlikte, milliyetçilik söz konusu olduğunda en az yaşanan geçmişin kendisi kadar geçmişin nasıl yorumlandığı da önemlidir. Renan'ın (1994, s. 17-18) meşhur sözünde söylediği gibi: "Uluslar için aslolan ona dâhil olan bireylerin pek çok ortak noktası olması kadar, pek çok ortak şeyi unutmuş olmalarıdır." IIlaveten, Hobsbawm ve Ranger'ın (1983, s. 13) tespit ettiği gibi ulusal ideolojilere mal edilen tarih, aslında görevli kişilerce seçilmiş, yazılmış, resmedilmiş, popülerleştirilmiş ve kurumsallaştııııış olan tarihtir.

Aslında tarihin aktarıırken hikâyeleştirilmemesi mümkün değildir. Çünkü bir tarih nesnesini birden çok şekilde anlatmak mümkündür. Hayden White'ın (1978, s. 90) da başarılı bir şekilde ortaya koyduğu gibi, bir dizi tarihsel vaka bir araya gelerek kendiliklerinden tamamlanmış bir hikâye meydana getirmezler. Bu durum hem kişisel olaylar hem de kurumlara, uluslara ve topluluklara ilişkin hikâyeler için geçerlidir. Olayların tarihsel dizimi birden çok şekilde anlatılabilirken, bu farklı anlatımlar da farklı yorum ve anlamlarla taçlanılar (White, 1978, s. 85). 
Ulusal kimlik inşası ideolojik altyapı gerektiren karmaşık bir süreçtir. Bu altyapı da çoklukla kullanışlı bir geçmişin yaratımasına dayanır. Ayrıca, tarihsel anlatılar siyasal kültürün önemli bir kısmıdırlar ve vatandaşlık yasaları da bu kültürün içinde şekillenir. Azaryahu ve Kellerman (1999, s. 110) kolektif hafızayı grup kimliğinin temelinde görür çünkü onlara göre kolektif hafıza, en temel soru olan "biz kimiz?" sorusunu "nereden geliyoruz?" sorusunun cevabıyla cevaplar. Bir grubun tarihini nasıl anladığı o grubun geçmişte ne olduğu, şimdi ne olduğu, ne olabileceği ve ne olması gerektiği konusunda o grubu koşullandırır. Dolayısıyla tarihin anlatıış̧ biçimi bir grubun başka gruptan insanlarla etkileşimini, uluslararası siyasetteki tutumunu ve içerideki çoğulculuğunu etkiler (Liu ve Hilton 2005, s. 537).

Tarihsel anlatılar ulus inşa etme projelerini ulusun kendini anlama biçimine dönüştürürler. Bu sebeple, sadece tarihin kendisini, olayların zamanlama ve dizilimini değil, aynı zamanda tarihin yorumlanış ve anlatıış biçimini de ayrıntılı olarak incelememiz gerekmektedir. Bu inceleme sonucunda ne tür tarihsel anlatıların ne tür vatandaşlık söylemlerinin kurumsallaşmasında rol oynadığının da açıkça sistematik olarak ortaya konması gerekir. Yine bu eksikliği klasik bir çalışmadan örnek vererek açıklayabiliriz. Brubaker (1992), Almanya ve Fransa'da değişik vatandaşlık politikaların kurulmasından iki ülkenin farklı siyasal ve kültürel geçmişlerini sorumlu tutmaktadır. Ona göre Fransa'nın devlet merkezli, asimilasyoncu ulus anlayışının baskın olmasını Fransa'da devletin ulus fikrinden önce konsolide olmasına, Almanya'da etnokültürel ve farklılaştırıcı milliyetçiliğin egemen olmasını da orada koşulların Fransa'dakinin tersine işlemiş olmasına bağlamak gerekir. Brubaker'e (1992, s. 16) göre, Fransa'da devletin kurumsal olarak sağlamlaşmış olması, Fransız devletinin asimilasyoncu güçlerine güvenmesini sağlamış ve ikinci nesil göçmenleri Fransız vatandaşı yapan yasa da böylece yasallaşmıştır.

Yukarıda tartışılan konular ışığında akla gelen soru kurumlara karşı bu tarz bir güvenin kişiden kişiye, kurumdan kuruma ve nesilden nesile nasıl aktarılığıdır. Ulusal kimlik anlayışları nesilden nesile pasif ve otomatik olarak aktarılmazlar. Tarih yazımı aktif bir süreçtir ve seçkinler bunu ulus inşa etme sürecinde yaygın şekilde kullanır. Belli tarihsel anlatıların kurumsallaşması da siyasal bağlam ve iradeden bağımsız düşünülemez. Bu bağlam dâhilinde üretilen ve tebliğ edilen tarihsel anlatılar farklı ülkelerde farklı kimlik ve azınlık politikalarının kabul görmesinde ya da reddedilmesinde önemli rol oynarlar.

Kolektif hafızaya ve tarihsel anlatılara eğilen siyaset bilimciler bu konuların güven aşılama ve değerli hissettirme (Smith, 2003, s. 69-70) ile toplumsal kapital oluşturma ve güven verme (Rothstein, 2005) gibi konularda ne derece hayati bir role sahip olduklarını ortaya koymaktadırlar. Buradan hareketle, azınlık politikaları konusunda güven aşılama ve toplum yapısını bozmadan başkalarını gruba dâhil edebilme gibi meseleler söz konusu olduğunda tarihsel anlatılar merkezi bir rol oynar. 
Kimlik ve kolektif hafızanın çalışılma biçimlerinde tespit edilen eksiklikler yakın tarihli bir çalışmaya önemli bir motivasyon kaynağı olmuştur (Uğur Çınar, 2015). Bu çalışmada tarih anlatım biçimleri ve vatandaşlık politikaları ilişkisi irdelenirken tek bir ülkenin ötesinde siyaset biliminin geneline katkıda bulunacak çıkarımlara ulaşmaya çalışılmıştır. Bunun için, hem karşılaştırmalı bir bakış benimsenmiş, hem de tarihsel anlatıların bir tipolojisi geliştirilip hangi biçime sahip anlatıların hangi vatandaşlık modellerinin kurumsallaşmasını kolaylaştırıp ne tür kimlik politikalarını zorlaştırdığını ortaya koyan bir model oluşturulmuştur. Bunu yaparken siyaset bilimi literatürünün dışında sosyoloji, felsefe, edebiyat eleştirisi, histografya vb. alanlardaki çalışmalardan da faydalanılmışır. Söz konusu alanlardaki birikim ana akım karşılaştırmalı siyaset literatürünün vatandaşlık çalışmalarında baskın olan kurumsal teorilerle harmanlanınca ortaya yeni bir araştırma odağı çıkmışır. Bu kavramsal çerçeveyi ileri taşımak adına Türkiye ve Avusturya iki imparatorluğun çekirdek ülkesi olarak karşılaştırmanın temelini oluştururken, modeli oluşturduktan sonra modelin Meksika ve İsrail gibi ülkeler için de uygulanabilirliğine bakılmıştır. Bulguların, milliyetçilik, vatandaşlık, siyasal kurumların dizayn edilişi ve çokkültürlülük açısından açtığı yeni çalışma alanları da ayrıca tartışımıştır.

Tarihsel anlatıların vatandaşılık ve azınlık politikaları açısından birer direnç noktası oluşturup farklı yönde yasaların geçmesini ya da bu yasalar geçse bile uygulanmalarında güçlük yaratacağını söylemek elbette ki vatandaşlık politikalarında değişimi imkânsız kıldıkları anlamına gelmemektedir. Bu ilişkiyi tek boyutlu düşünmek yerine fizikten bildiğimiz bileşke kuvvet kavramı ile açıklayabiliriz. Buna göre, eğer vatandaşlık politikalarının izlediği yön bileşke kuvvetimiz, yani bir cisme farklı yönlerde uygulanan kuvvetlerin oluşturduğu net etki ise, resmi tarih yazımı da bu bileşkeye etki eden önemli kuvvetlerden biridir (Uluslararası faktörler, ülke içi başka dinamikler vs. diğer vektörleri oluşturur). Kuvvetler, yönlü birer doğru olan vektörlerle ifade edilirler. Türkiye örneğine uygulamak gerekirse, çoğulcu vatandaşlık politikalarının uygulanmasına yönelik kuvvetler birer vektör olarak değerlendirilirse homojen anlatısı ile Türkiye'de resmi tarih bu sözü edilen diğer vektörlerle zıt yönde kuvvet uygulamaktadır. Her ikisinin birbirini tamamen ortadan kaldırıp bileşkenin sıfır olacağını iddia edemeyiz ancak bileşke vektörün beklenenden daha kısa olacağını söyleyebiliriz.

\section{Kolektif Hafıza ve Kurumsal Dizaynın İlişkisi}

Kolektif hafızanın toplulukların kimlik inşasında oynadığı önemli rol bizi siyasal kurumların yapısı üzerinde kolektif hafızanın rolünü de düşünmeye sevk etmelidir. Nasıl ki farklı vatandaşlık modellerini tarihsel anlatılara bakmadan anlayamıyorsak, kurumsallaşmış hafızanın bıraktığı etkiyi anlamadan yeni kurumların inşa sürecini de anlamak mümkün olmayacaktır. Sözünü ettiğimiz yeni kurumların inşasına yeni anayasa yapım süreçleri, kurumsal reform, güç paylaşımı ve etnik çatışmayı sona erdirici kurumların oluşturulması da dahildir. Bu tarz kurumsal düzenlemeler genel olarak bizim nasıl bir topluluğa dahil olduğumuza 
dair inancımız ve nasıl bir topluluk görmek istediğimizle doğrudan ilintilidir. Bu sebeple, Winslade ve Monk'un (2001) da iddia ettiği gibi, çıkar tabanlı bir çatışma çözümü analizi, dilin ve anlatıların sosyal kurgular üzerindeki etkisi göz önünde bulundurularak tekrar gözden geçirilmelidir. Buna göre, rasyonel seçim teorisinin varsaydığının tersine, çıkarlar ve tercihler etnisitelerin nesnel kategorizasyonlarının birer ürünü değildirler ve sadece etnik grupların görece güç pozisyonlarına göre şekillenmezler. Hal böyleyken, eştoplumlaştırmacılık (consociationalism) ${ }^{1}$ üzerine çalışmaların bile kolektif hafızayı ve tarihsel söylemi modellerinin önemli bir unsuru haline getirmemeleri tuhaftır. Örnek olarak, eştoplumlaştırmacı modelin kurucusu olan Lijphart, kolektif hafızayı bu modelin sağlanabilmesi için gerekli koşullar arasında saymamaktadır (eştoplumlaştırmacılığı sağlayan olumlu koşullar için bknz. Bogaards, 1998; Andeweg, 2000).

Aslında çatışma çözümü literatüründeki bu eksiklik literatürün önde gelen isimlerinden Horowitz' in (2002) de dikkatini çekmiştir. Çatışma çözücü kurumların oluşmasında belirleyici unsurlar arasında Horowitz tarihsel yargıların kurum seçimi üzerindeki etkisinden de söz etmektedir. Buna göre, hem tarihsel deneyim hem de bu deneyimlerim yorumlanış biçimi kurumsal seçimleri etkilemektedir. Horowitz de şu zamana dek kolektif hafızanın kurumsal dizayn üzerindeki etkisine bakan çalışmaların bulunmayışını hayretle karşılamaktadır. Horowitz'e göre standart (one-size fits all) çözümlerin öne sürülmesi tarihsel önyargılar hesaba katılmadığında hayal kırıklığı ile sonuçlanacaktır. Horowitz bu konuyu bir öneri olarak bırakmakta ancak kendisi çalışmasını bu yönde ilerletmemektedir.

Kurumsal yapı açısından bakıldığında bir ülkenin parti sistemi de bu bağlamda değerlendirilebilir. Bu yönden öncü bir çalışma olarak David Art'ın The Politics of the Nazi Past in Germany and Austria'sından söz edilebilir. Art'ın çalışmasında gösterdiği gibi, geçmişin nasıl anıldığı ve geçmiş hataların yeterince kabul edilip edilmediği önemli siyasal sonuçlara yol açmaktadır. Art’ın Almanya ile Avusturya'yı karşılaştırmalı olarak çalışması, kolektif hafızanın aşırı sağ partilerin yükselişi üzerindeki etkisini ortaya koymuştur. Kolektif hafızanın Almanya'da Nazi döneminin hatalarını kabul eder biçimde şekillenmesi siyasal partilerin, medya ve sivil toplumun aşırı sağ partilere karşı sert bir tutum takınmalarına sebep olurken, Avusturya'da böyle bir hata kabulünün kolektif hafızaya yerleşmemiş olması aşırı sağ partilerin yükselişini kolaylaştırmıştır (Art, 2006, s. 146).

\section{Bir Kimlik Mücadelesi Alanı Olarak Kolektif Hafıza}

Kolektif hafızanın grup üyelerini bir arada tutucu özelliği onu çalışanlarca kimi zaman vurgulanmıştır. Örnek olarak, Confino (1997) kolektif hafıza çalışmalarında ortak paydaların önemine vurgu yapmıştır. Gildea'nin The Past in

1 Eştoplumlaştırmacılık etnik, dinsel vb. nedenlerle derin ayrışmaların olduğu toplumlarda çözüm amaçlı ortaya atılmış bir kurumsal modeldir. Bu modele göre farklı grupların siyasi sistem içinde temsil edilmesi belli oran ve kotalarla garanti altına alınmıştır. 
French History kitabını da Confino bu yüzden eleştirmiştir. İddiasına göre Gildea; sosyalistlerin, Bonapartistlerin, anarşistlerin ve bölgeselcilerin farklı hafızalarına eğilerek, Fransa'nın nasıl olup da tüm farklıklarına rağmen, bir ortak ulus olarak var olabildiği sorusunu yanıtsız bırakmaktadır. Confino'ya (1997, s. 1400) göre ulus olma bilincini temsil eden tarihsel unsurlara dikkat etmemiz gerekmektedir çünkü bu ulusal hafıza unsurları gerçek toplumsal ve siyasal çatışmaların sembolik anlamda üstesinden gelinmesini sağlamaktadırlar. Gerçekten de tarihsel anlatılar yoluyla siyasiler birden çok siyasi kanadın kesişim kümesi olabilecek nitelikte hikâyeler üreterek ortak bir payda sağlamada oldukça başarılıdır. Resmi tarih, yazılış biçiminin genel karakteri ve birden fazla yorumlama biçimine açık oluşu nedeniyle siyasi yelpazede kolayca birden fazla siyasi görüşün kapsamı dâhilinde kalabilir. Farklı gruplar tarihsel olayların ayrıntıları konusunda hemfikir olmayabilirler ancak tarihsel anlatının genel kapsamı bu ayrıntıların ötesinde bir kapsayıcılık gösterebilir. Ancak bu kapsayıcılık bizim kolektif hafızanın siyasetin tam orta yerinde olduğu gerçeğini anlamamıza engel olmamalıdır. Zerubavel'in (1995, s. xix) de belirttiği gibi, kolektif hafıza bir taraftan sosyal dayanışmayı güçlendirici bir faktörken, aynı zamanda güç ve kontrol mücadelesi için önemli bir arenadır da. İsrail'de kolektif hafızaya bakan Zerubavel (1995, s. 147) burada tarihsel olayların farklı yorumlamalarının İsrail'de rekabet halinde olan farklı kolektif hafıza modellerine ve bunlara paralel olarak farklı siyasal ajandalara işaret ettiklerini saptamıştır. Kolektif hafızanın sadece toplumsal birlik sağlamadığını, aynı zamanda ayrışııııı bir kültürel güce dönüşebileceğinin bir kanıtı olarak da Yahudi tarihinin Siyonist seküler milliyetçi yorumuna milliyetçi-dindar yorum tarafından nasıl meydan okunduğunu göstermektedir. Aynı şekilde, Davis (2005) de Irak'ta Pan-Arabist ve Irakçı tarih anlayışlarını bu iki kamp arasındaki hegemonya mücadelesi kapsamında tartışarak kolektif hafızanın nası bir siyasal araç ve güç mücadelesi unsuru olduğunu ortaya koymuştur. Bu tespitler de bizi bir sonraki sorumuza götürmektedir: Peki, rekabet halinde hikâyeler varsa, her hikâyenin şansı eşit midir? Madun (subaltern) hikâyelerin hiç şansı yok mudur?

\section{Kolektif Hafıza ve Güç Asimetrileri}

Konu kolektif hafızanın biçimlendirilmesi ve yayılması olduğunda devletlerin konumu toplumsal aktörlere nazaran çok daha donanımlı ve bu sebeple de daha avantajlıdır. Benedict Anderson (1991) bu yönde devletlerin haritalar, müzeler ve nüfus sayımları yoluyla toplulukları nasıl şekillendirdiklerini izah etmiştir. Davis (1994) de aynı şekilde müzelerin Irak tarihindeki rolünden bahsetmektedir. Bu çalışmaların merkezinde kolonileştiren ve kolonileştirilen arasındaki ilişki vardır ancak aynı durum ulus-devletlerin yerel dinamikleri için de geçerlidir. Örnek vermek gerekirse, Shohat (1999) Siyonist anlatının Mizrahi Yahudiler'in kimlik ve tarihlerine önemli zararlar verdiğini savunur.

Bir ülkenin özellikle de kuruluş sürecinde kurumsallaşan tarihsel anlatılarının sonraki anlatıları büyük ölçüde kısıtladığı görülmektedir (Uğur Çınar, 2015). Bu durum, kurucu siyasal seçkin kitle artık görev başında olmasa bile geçerlidir. 
Lustick'in (1997, s. 156-157) de ifade ettiği gibi, ulusal tarih anlatımları yeni bilgi ve yeni soruları kolaylıkla kabul etmezler. Yine Wertsch'ten (2008, s.150-151) de öğrendiğimiz üzere tarihsel anlatım kalıpları şaşılacak düzeyde muhafazakârdır ve değişime karşı dirençlidir. Bu devamlılık durumunun sağlanmasında eğitim yoluyla getirilen kontrol ve standartlaştırmanın yanında, tarihsel anlatıların sosyalleşme üzerindeki rolü de etkili olmuştur. İnsanlar genç yaşlarından itibaren belli bir hikâye ile sosyalleştikten sonra, kendilerini bu hikâyeden soyutlamakta zorluk çekmektedirler; çünkü hem bireysel hem toplumsal kimliklerinin şekillenmesinde bu anlatılar önemli rol oynamışlardır.

Yine de resmi tarihin her şeyi kapsayıcı ve başka hiç bir tarihsel yoruma yer bırakmayacak kadar güçlü olduğunu söylemek abartılı olacaktır. Elbette ki burada içinde bulunulan rejimin ne derece çoğulcu olduğu, sivil toplumun ne kadar güçlü olduğu ve medyanın ne kadar devletten bağımsız olduğu gibi konular resmi tarih dışı anlatımların kendilerine ne kadar yer bulabildiklerini etkilemektedir. Mesela, Bodnar çalışmalarında ABD'ye odaklanarak, resmi hafıza ile yerel (vernacular) hafıza arasındaki dinamiği incelemiştir. Bodnar'a göre kolektif hafıza, resmi hafıza ile yerel hafızanın kesişiminden doğmaktadır. Ona göre siyasal seçkinler her ne kadar tarihsel anmaları kendi istedikleri yönde şekillendirmek istemiş olsalar da, bunda hiç bir zaman tamamen başarılı olamamışlardır. Kamusal hafızaya halen daha büyük ölçüde seçkin manipülasyonu şekil verse de gündelik hayatta sıradan insanlar bu çabaları kimi zaman kabul ederken, kimi zaman yeniden formülize etmiş, kimi zaman da tamamen göz ardı etmişlerdir (Bodnar, s. 20).

Wertsch bize kurumsallaşmış ve alternatif tarih anlatıları arasındaki ilişkileri çalışmak için önemli bir kavramsal araç hediye etmektedir. Bakhtin'den yola çıkan Wertsch (2000) onun metinlere uyguladığı yöntemi tarihsel söylem kalıplarına uygulamaktadır. Ona göre, bir ülkede tarihsel anlatı mücadelesini anlamak için sadece mevcut metinleri okumak yetmez, aynı zamanda o metinlerin ve söylemlerin kendilerinden önce gelenlere nasıl yanıt verdiklerini de anlamak gerekir. Wertsch, bunu yaparken de Bakhtin'in saklı diyalojizm (hidden dialogicality) kavramından faydalanır (2000, s. 526). Bakhtin'in burada saklı diyalojizmden kastettiği şudur: Her söz ya da söylem aslında kendisinden önce söylenen bir şeye cevap niteliğindedir (Bakhtin, 1986, s. 92). Bir diyaloğu saklı yapan da biz diyalog içine girilen tarafı duyamasak da söz ya da söylemde karşı tarafın etkilerini görüyor olmamızdır (Bakhtin, 1984, s. 199). Wertsch, örnek olarak da Sovyet sonrası Rus ders kitaplarının Sovyet dönemi kitapları ile girdiği diyaloğu göstermektedir. Wertsch'in yöntemi başka çalışmalarda, hatta aynı anda rekabet halinde olan birden çok kolektif hafızanın birbiriyle ilişkisini incelemek için de kullanılabilir.

Kurumsallaşmamış olan tarih anlayışlarının ana akımda kendine yer bulmasında devrimler ya da yönetimdeki hegemonyal bloklarda yaşanan büyük değişiklikler oldukça büyük etki sahibidir. Dolaysıyla, kolektif hafıza çoklukla devlet destekli politikalarla şekillenirken, devlette hakim olan grup ve söylemde 
meydana gelecek keskin değişiklikler kolektif hafızanın içeriğini de etkileyebilir ve o zamana dek marjinal olarak varlığını sürdüren hikayelerin baskın hale gelmesini sağlayabilirler. Bunun için önemli olan kendine ana akım kolektif hafıza anlatılarında yer bulamayan hikayelerin varlığını toplumsal düzeyde sürdürüyor olmasıdır. Bugüne dek aileler içinde ve yeraltı örgütlenmelerde ya da sadece belli gruplar arasında etkinliğini sürdüren medya organlarında saklanan ve aktarılan böylesi hikayeler, özellikle internet ve sosyal medyanın yaygınlaşmasıyla devletçe kurumsallaştırılmış kolektif hafızalar karşısında daha iyi organize olma şansı yakalıyor olabilirler. Bu durumun gelecekte devlet ve toplum arasında kolektif hafıza bağlamında yaşanacak etkileşimi nasıl etkileyeceği sorusu ise önemli çalışmalara temel oluşturabilir.

\section{Kolektif Hafızanın Kimlik Üzerindeki Öngörülemeyen Etkileri}

Bir ülkede resmi tarihin alacağı şekli belirleyen pek çok faktör vardır. Resmi tarihin alacağı şekil, siyasal seçkinlerin çıkarları (Hobsbawm ve Ranger, 1983) ile tarihsel geçmişin (Schudson, 1989, s. 105-113; Schwartz, 1991, s. 221-236) bir kombinasyonudur. Devletçe desteklenen kimlik politikalarının da bu tarihin şekillenmesindeki rolü büyüktür (Wertsch 2008, s. 60). Ancak burada dikkat etmemiz gereken bir husus bulunmaktadır. Aslında çoğu zaman kolektif hafıza ve kimlik konusu işlenirken işlevselci bir yaklaşıma kapılmak mümkün olabilir. Böylesi bir hikâye uyarınca siyasi girişimciler kafalarında kurguladıkları ulusu inşa etmek için ona uygun bir tarih yazdırır ve bunu kurumsallaştırırlar. Oysaki gerçek durum bundan farklıdır. İlk olarak, kurumsallaşan tarih monolitik bir siyasal seçkin kadronun eseri olmaktan ziyade, birden çok grubun uzlaşması ya da karşılıklı ödün vermesi sonucunda oluşmuş olabilir. Dahası, ampirik örneklere girilince görülecektir ki bir tarihsel anlatının kurumsallaşmasına neden olan faktörler o anlatının ortaya koyacağı vatandaşlık politikalarından farklı olabilir. Bir başka deyişle, anlatının kurumsallaştığı ilk bağlam, tarihsel anlatının uygulandığı şimdiki bağlamdan çok farklı olabilir. Dolayısıyla, kurumsallaşmış tarihsel anlatılar hiç beklenmeyen sonuçlara kapı aralayabilirler çünkü ilk başta öngörülemeyen amaçlara hizmet edebilirler.

Birkaç örnekle bu durumu daha net açıklayabiliriz. Örneğin Avusturya'da çoğulcu bir tarih yazımının benimsenmesinin nedeni otokton azınlıklara tarihsel meşruiyet kazandırmak değildi. Bundan ziyade, amaç Avusturya'nın Almanya'dan farklarını ortaya koyarak Avusturya'yı Aımanya'dan, dolayısıyla da Nazi geçmişinin suçlarından uzaklaştırmaktı (Uğur Çınar, 2015). Bu amaçla İkinci Dünya savaşı sonrası Avusturya seçkinleri etnik olmayan bir tarihsel soy kütüğü oluşturma girişiminde bulundular. Yine de Avusturya'nın tarihi, azınlıklar hatırına çoğulcu ve bağlamsal bir anlatıma kavuşmamış olsa da, uzun vadede pek çok siyasi arenada bu amaç için kullanılmıştır. Aynı şekilde, Meksika'da 1910 Devrimi sonrasında Meksika'yı ABD'den ayrı bir yapı olarak meşrulaştıracak kültürel otantik bir kimlik yaratma kaygısı, yerli, melez mestizo'nun kültürel mirasına dayalı zengin ve özgün bir tarih yazımına yol açmıştır. Görüleceği üzere, devletlerin arzu edilen 
bir etnik kimlik inşa etmenin yanı sıra başka kaygıları da vardır ve bu kaygılar da tarih yazımı üzerinde etkilidir. Bu kaygılar başlangıçta o ülkede izlenecek olan azınlık politikasından bağımsız da görünse, uzun vadede ülkede bulunan azınlıklar için önemli sonuçları olabilecektir. Zira bu tarihsel söylem, grup haklarının talep edilmesinde önemli bir meşrulaştırıcı rol oynayacaktır.

Avusturya ile Meksika'nın sınır ötesi kaygılarının yerelde oluşturdukları tarih anlatım biçimlerinin etkisi ve bu tarih anlatım biçimlerinin azınlık politikalarına etkisi konusu bizi bir sonraki sorumuza getirmektedir: Kolektif hafıza açısından ulusal ve uluslararası dinamikler birbiriyle nasıl etkileşim halindedir?

\section{Kolektif Hafızanın Sınır Ötesi Dinamikleri}

Kimliklerin etkileşimli olarak, birbiriyle olan ilişkileri üzerinden kurulduğu gerçeği sosyal bilimlerde genel kabul görür. Kimlikler çoğu zaman grup üyelerinin kim oldukları kadar kim olmadıklarıyla da ilgilidirler ve bu çerçevede kurulurlar (Benhabib 1996, s. 3; Guibernau, 2007, s. 10; Abdelal vd., 2006, s. 698). Hal böyleyken, sınır ötesi faktörlerin kolektif hafıza çalışmalarında yeterli derecede çalışılmaması ilginçtir. Örneğin, Anthony Smith (1999, s. 206) The Ethnic Origins of the Nations isimli kitabında tarihin sunuluş biçiminin "ülke sınırları içinde önde gelen sosyal grupların ve kurumların bir diyaloğunun ürünü" olduğunu savunmaktadır. Bu formülasyon resmi tarihin önemli bir boyutuna parmak basarken sınır ötesi faktörlerin tarih yazımındaki rolünü göz ardı etmektedir.

Bu anlamda sınırlar önemli bir çalışma alanıdır (Ellis vd., 2009; Frank ve Hadler 2011). Ancak sınırların kolektif hafıza ile ilişkisini ortaya koyan pek çok çalışma fazlasıyla mikro düzeyde sınırlara ve bölgelere odaklanmaktadır. Durum böyle olunca da bu sınırlara ilişkin kaygıların resmi tarih söyleminin bütününe nasıl yansıdığı ve azınlıklar için ne gibi çıkarımları olduğu konusu da yeterinde ele alınmamıs oluyor. Bu sebeple hem lokal ve bölgesel olanın, hem de sınır ötesi ve küresel olanın ulusal hafızaya nasıl etki ettiğine bakmamız gerekecek. Yukarıda sözü edilen hem Avusturya hem de Meksika örneklerinde sınır ötesi gelişmelerin ve kaygıların ulusal düzeye kolektif hafızanın şekillenmesinde ne gibi rol oynadığına bakmak da bu bakımdan faydalı olacaktır. Her iki ülkede de sınır boylarında ve sınır ötesindeki dinamikler, ülkelerdeki yerel özelliklerin tarih anlatımında ön plana çıkarılmasına neden olmuştur. Bu özellikler, uluslararası şartlar değişmeden önce, örneğin Meksika'da devrim öncesi ABD ilişiklilerinde ve İkinci Dünya Savaşı Avusturya'sında bu özellikleri göstermemekteydiler. Meksika'da da Otantik mestizo kültürüne vurgu ancak Meksika'nın kendisini ABD'den ayrıştırma çabasıyla ve kendisinin artık manipüle edilebilir bir kolonyal toprak olmadığını kanıtlama çabasıyla olmuştur (Schmidt, 1978, s. 57). Aynı şekilde, Avusturya'da Nazi suçlarından ve Almanya'dan uzaklaşma çabaları yokken imparatorluk tarihinin çokkültürlü yapısına vurgu yapılmamaktaydı. 
Thaler (2001, s. 187) Avusturya örneğinin keskin kültürel ayrımların yapılamadığı ulusal çevreleri anlamak için önemli olduğunu söylemektedir. Thaler'in ortaya koyduğu başkaca örnekler Rusya, Beyaz Rusya ve Ukrayna, ABD-Kanada, Sırbistan ve Karadağ, İskoçya ve Britanya, Lombardiya ve İtalya gibi vakalardır. Buradan hareketle aynı vak alar ve daha fazlaları yine bu belirsiz ilişkinin tarih yazımını ve dolayısıyla vatandaşlık politikalarını nasıl etkilediği soruları üzerinden çalışılabilir. Ayrıca bu tür çalışmaların kapsamı Ortadoğu gibi sınır ötesi kimlik inşaları, irredantizm ve pan-hareketlere şahit olmuş başka alanları da içine alacak şekilde genişletilebilir.

\section{Sonuç}

Bu yazıda kolektif hafıza literatürünün genel bir değerlendirmesi yapılırken, aynı zamanda da çalışılmayı bekleyen sorulara ve gelecekte açılabilecek yeni araştırma alanlarına değinilmiştir. Literatürde dikkati çeken en önemli eksiklik olarak karşılaştırmalı çalışmaların azlığı göze çarpmaktadır ve bu durum da genel kuramsal çıkarımlar yapmayı zorlaştırmaktadır. Buna ek olarak, literatürlerin kendi aralarında gruplanması ortak bir kolektif hafıza literatürü dahilinde çalışmaların birikimli ilerlemesini zorlaştırmaktadır. Örnek olarak vatandaşlık çalışmaları gibi alanlarda kolektif hafızanın kimlik inşası üzerinde yarattığı doğrudan etkinin yeterince çalışılmaması gösterilebilir.

Bu genel husus dışında kolektif hafıza konusu çalışıırken göz önünde bulundurulması yararlı olacak bazı hususlar vardır. Bunlardan ilki kolektif hafızanın birleştirici ve ortak kimlik yaratıcı rolü kadar kutuplaştııı ı ve gruplar arası ya da grup içi çatışma dinamiklerini şekillendirici etkisi olduğu gerçeğidir. Bir diğer bulgu fonksiyonalizmi yani işlevselciliği aşırıya taşımayan ve öngörülemeyecek sonuçlara yer bırakan bir kolektif hafıza-kimlik analizinin gerekliliğidir.

Yukarıdaki tespitlere ek olarak, değişen şartların kolektif hafıza-kimlik ilişkisi üzerinde yaratacağı etkinin çok yönlü akademik çalışmalara olanak sağlayacağı da aşikardır. Eğer makalede belirtildiği gibi kolektif hafıza toplumsal kimlikler üzerinde etki sahibi ise ve kolektif hafıza medya, sinema gibi iletişim araçları ile yayılıyorsa, değişen iletişim araçlarının da yeni hatırlama biçimleri ve ulusdevleti aşabilecek yeni topluluk kurgularına yol açması beklenebilir. Bu durum da bize kolektif hafıza-kimlik ilişkisinde yeni çalışma alanları açabilir. Örnek olarak "küreselleşme ve sosyal medyanın yaygınlaşması yeni hatırlama ve aidiyet biçimlerine yol açabilir mi?" sorusuna cevap arayabiliriz. Bu alandaki değişiklikler ve yeni trendler iletişim çalışmaları açısından da yeni çığırlar açabilir.

Burada ayrıntılı olarak değinilen konular dışında kolektif hafızaya dair daha başka sorular da bulunmaktadır. Örnek olarak, "Geçmişi ele almanın siyaseten en sağlıklı yolu nedir? (Bunun için bknz. Curry, 2007; Bar-Tal ve Bennick, 2004; Misztal, 2010; Encarnacion, 2008)" sorusunu ele alabiliriz. Geçmiş hataları hatırlamak, hataların bir daha tekrarlanmaması ve adaletin sağlanması 
açısından önemlidir. Ancak şunu da sormak gerekir: Bir nefret çemberinden, bir kısır döngüden çıkacak şekilde, evrensel insanlık değerleri üzerine kurulmuş bir hatırlayış nasıl sağlanabilir? Intikam duygularını ve karşılıklı stereotipleri derinleştirmeyen bir hatırlama nasıl geliştirilebilir? Güncelliğini koruyan başka bir sorular bütünü nostalji konusunu kapsamaktadır. Geçmişe dair nostalji ne şekilde ele alınmalıdır? Dayatmacı ve totaliter olmayan bir nostalji mümkün müdür? Nostaljinin siyasal dinamikler içinde rolü nedir? (Nostalji için bknz. Boym, 2007; Pickering ve Keightley, 2006; Tannock, 1995; Özyürek, 2007b; Muro, 2005). Belki de tüm soruların altında yatan meta-sorular şununla ilgilidir: Ulus-devletlerin ve neoliberalizmin tektipleştirici etkisine rağmen çokkültürlülük bizimledir. Öyleyse, daha katıımc topluluklar yaratmak üzere tarih yazımında ne gibi reformlara gidebiliriz ve kültürel miras politikalarını nasıl şekillendirebiliriz? Bir arada çoğulcu bir şekilde yaşamanın şartlarının oluşmasında ya da oluşamamasında siyasal söylemin ve aktarılagelen toplumsal anlatıların rolü nedir?

Bu değerlendirme yazısından çıkaracağımız bir diğer sonuç da metodolojik ve kuramsal çoğulculuk hakkındadır. Burada üzerinden geçilen çalışmalar tarih, edebiyat, medya çalışmaları, sosyoloji, felsefe, siyaset bilimi, psikoloji gibi pek çok disiplin altında ve bu disiplinlerin kesişiminde yazılmıştır. Dolayısıyla, disipliner sınırlardan ziyade sorduğumuz akademik soruların araştırmamızı yönlendirmesine izin vermek çok daha donanımlı ve çok yönlü çalışmaların ortaya konulmasını sağlayacaktır. Yine görüyoruz ki en faydalı kolektif hafıza çalışmaları tek bir vaka üzerinde çalışsalar dahi mevcut literatürle tartışmaya giren ve bulgularının genel olarak kolektif hafıza çalışmaları adına yaptıkları katkıyı açıkça ortaya seren çalışmalardır. Sorularına interdisipliner ve çoğulcu yanıtlar arayarak başlayan araştırmaların toplumsal ve akademik çoğulculuğa da katkı sağlayacağı açıktır.

\section{Kaynakça}

Anderson, B. (1991). Imagined Communities. London: Verso.

Art, D. (2006). The Politics of Nazi Past in Germany and Austria. Cambridge: Cambridge University Press.

Assmann, J. (2008). Communicative and Cultural Memory. A. Erll ve A. Nünning (Ed.), Cultural Memory Studies: An International and Interdisciplinary Handbook içinde (109-118). Berlin: Walter de Gruyter.

Assmann, J. (1992). Das Kulturelle Gedächtnis: Schrift, Erinnerung und Politische Identität in Frühen Hochkulturen. Munich: Verlag C.H. Beck.

Azaryahu M. ve A. Kellerman (1999). Symbolic Places of National History and Revival: A Study in Zionist Mythical Geography. Transactions of the Institute of British Geographers, 24(1), 109-123.

Bakhtin, M. (1986). Speech Genres and Other Late Essays. Texas: University of Texas Press. 
Bakhtin, M. (1984). Problems of Dostoyevsky's Poetics. Minnesota: University of Minnesota Press.

Bar-Tal, D. ve G. H. Bennink (2004). The Nature of Reconciliation as an Outcome and as a Process. Y. Bar-Siman- Tov (Ed.), From Conflict Resolution to Reconciliation içinde (11-38). Oxford: Oxford University Press.

Berger, S., M. Donovan ve K. Passmore. (Ed.). (1999). Writing National Histories: Western Europe Since 1800. New York: Routledge.

Bodnar, J. (1994). Public Memory in an American City: Commemoration in Cleveland. Gillis, J.R. (Ed.), Commemorations: the Politics of National Identity içinde (74-89). Princeton: Princeton University Press.

Bogaards, M. (1998). The Favourable Factors for Consociational Democracy: A Review. European Journal of Political Research, 33, 475-496.

Boym, S. (2007). Nostalgia and Its Discontents. Hedgehog Review, 9(2), 7-18.

Brockmeier, J. (2002). Remembering and Forgetting: Narrative as Cultural Memory. Culture Psychology, 8, 15-43.

Brubaker, R. (1992). Citizenship and Nationhood in France and Germany. Cambridge: Harvard University Press.

Bruner, J. (1991). The Narrative Construction of Reality. Critical Inquiry 18(1), $1-21$.

Confino, A. (1997). Collective Memory and Cultural History: Problems of Method. The American Historical Review, 102(5), 1386-1403.

Connerton, P. (1989). How Societies Remember. Cambridge: Cambridge University Press.

Curry, J. L. (2007). When an Authoritarian State Victimizes the Nation: Transitional Justice, Collective Memory, and Political Divides. International Sociological Review, 37(1), 58-73.

Davis, E. (2005). Memories of State: Politics, History and Collective Identity in Modern Iraq. Berkeley: University of California Press.

Davis, E. (1994). The Museum and the Politics of Social Control in Modern Iraq. J. R., Gillis (Ed.), Commemorations: the Politics of National Identity içinde (90-104). Princeton: Princeton University Press.

Ellis, S. G. ve R. Esser. (Ed.). (2009). Frontiers, Regions and Identities in Europe. Pisa: Pisa University Press.

Encarnación, O. G. (2008). Reconciliation after Democratization: Coping with the Past in Spain. Political Science Quarterly, 123(3), 435-459.

Errl, A. (2011). "Travelling Memory," Parallax, 17 (4), 4-18. 
Frank, T. ve F. Hadler (Ed.). (2011). Disputed Territories and Shared Pasts: Overlapping National Histories in Modern Europe. New York: Palgrave Macmillan.

Gillis, J. R. (Ed.). (1994). Commemorations: the Politics of National Identity. Princeton: Princeton University Press.

Halbwachs, M. (1980). The Collective Memory. New York: Harper \& Row Colophon Books.

Hirsch, M. (2008). The Generation of Postmemory. Poetics Today, 29(1),103-128.

Hobsbawm, E. J. ve T. Ranger (Ed.). (1983). The Invention of Tradition. Cambridge: Cambridge University Press.

Horowitz, D. (2002). Constitutional Design: Proposals versus Processes. A. Reynolds (Ed.), The Architecture of Democracy: Constitutional Design, Conflict Management, and Democracy içinde (15-36). Oxford: Oxford University Press.

Kansteiner, W. (2002). Finding Meaning in Memory: A Methodological Critique of Collective Memory Studies. History and Theory, 41(2), 179-197.

Landsberg, A. (2003). Prosthetic Memory: The Ethics and Politics of Memory in an Age of Mass Culture. P. Grainge (Ed.), Memory and Popular Film içinde (144161). Manchester: Manchester University Press.

Levy D. ve N. Sznaider (2002). Memory Unbound: The Holocaust and the Formation of Cosmopolitan Memory. European Journal of Social Theory, 5, 87106.

Liu J. H. ve D. J. Hilton (2005). How the Past Weighs on The Present: Social Representations of History and their Role in Identity Politics. British Journal of Social Psychology, 44, 537-556.

Lustick, I. S. (1997). Israeli History: Who is Fabricating What? Survival: Global Politics and Strategy, 39(3), 156-157.

Maclntyre, A. (2007 [1981]). After Virtue: A Study in Moral Theory (3. Baskı). Notre Dame: University of Notre Dame Press.

Misztal, B. A. (2010). Collective Memory in a Global Age: Learning How and What to Remember. Current Sociology, 58(1), 24-44.

F. Şenol Cantek ve G. Orhon (Ed.). (2014). Bellek Özel Sayısı Moment Dergisi, $1(2)$.

Muro, D. (2005). Nationalism and nostalgia: the case of radical Basque nationalism. Nations and Nationalism, 11(4), 571-589.

Neyzi, L. (Ed.). (2011). Nasıl Hatırlıyoruz? Türkiye'de Bellek Çalışmaları. İstanbul: İş Bankası Kültür Yayınları.

Nora, P. (1989). Between History and Memory: Les Lieux de Memoire. Representations, 26, 7-24. 
Olick, J. K. (Ed.). (2003). States of Memory: Continuities, Conflicts, and Transformations in National Retrospection. Durham: Duke University Press.

Olick, J. K. (1999). Collective Memory: The Two Cultures. Sociological Theory, 17(3), 333-348.

Olick, J. K. ve J. Robbins (1998). Social Memory Studies: From "Collective Memory" to the Historical Sociology of Mnemonic Practices. Annual Review of Sociology, 24, 105-140.

Özyürek, E. (Ed.) (2007a). The Politics of Public Memory in Turkey. Syracuse: Syracuse University Press.

Özyürek, E. (2007b). Public Memory as Political Battleground: Islamist Subversions of Republican Nostalgia. E. Özyürek (Ed.) The Politics of Public Memory in Turkey içinde (114-137). Syracuse: Syracuse University Press.

Peri, Y. (1999). The Media and Collective Memory of Yitzhak Rabin's Remembrance. Journal of Communication, 49(3), 106-24.

Pickering, M. ve E. Keightley (2006). The Modalities of Nostalgia. Current Sociology, 54(6), 919-941.

Poole, R. (2010). Misremembering the Holocaust: Universal Symbol, Nationalist Icon or Moral Kitsch? Y. Gutman, A. D. Brown ve A. Sodaro (Ed.), Memory and the Future. Transnational Politics, Ethics and Society içinde (31-49). London: Palgrave Macmillan.

Ricoeur, P. (1980). Narrative Time. Critical Inquiry, 7(1), 169-190.

Renan, E. (1994). What is a Nation? J. Hutchinson ve A. D. Smith (Ed.) Nationalism içinde (17-18). Oxford: Oxford University Press.

Roediger, III H. L. ve J. V. Wertsch, (2008). Creating a New Discipline of Memory Studies. Memory Studies, 1(1), 9-22.

Rothstein, B. (2005). Social Traps and the Problem of Trust. Cambridge: Cambridge University Press.

Schmidt, H. C. (1978). The Roots of lo Mexicano, London: Texas A \& M University. Shohat, E. (1999). The Invention of the Mizrahim. Journal of Palestine Studies, 29(1), 5-20.

Smith, A. D. (1994). Gastronomy or Geology? The Role of Nationalism in the Reconstruction of Nations. Nation and Nationalism, 1(1), 3-23.

Smith, R. M. (2003). Stories of Peoplehood: The Politics and Morals of Political Memberships. Cambridge: Cambridge University Press.

Somers, M. R. (1994). The Narrative Constitution of Identity: A Relational and Network Approach. Theory and Society, 23(5), 605-649.

Tannock, S. (1995). Nostalgia Critique. Cultural Studies, 9(3), 453-464. 
Taylor, C. (1989). Sources of the Self: The Making of the Modern Identity, Cambridge: Harvard University Press.

Thaler, P. (2001). Ambivalence of Identity: the Austrian Experience of Nationbuilding in a Modern Society. West Lafayette: Purdue.

Ugur Cinar, M. (2015). Collective Memory and National Membership: Identity and Citizenship Models in Turkey and Austria. New York: Palgrave Macmillan.

Van Andeweg, R. (2000). Consociational Democracy. Annual Review of Political Science 3, 509-536.

Winslade, J. ve G. Monk (2001). Narrative Mediation. San Francisco: JosseyBass.

Wertsch, J. V. (2000). Narratives as Cultural Tools in Sociocultural Analysis: Official History in Soviet and Post-Soviet Russia. Ethos, 28(4), 511-533.

Wertsch, J. V. (2008). Collective Memory and Narrative Templates. Social Research, 75 (1), 133-156.

White, G. M. (1999). Emotional Remembering: The Pragmatics of National Memory. Ethos, 27(4), 505-529.

White, H. (1978). Tropics of Discourse: Essays in Cultural Criticism. Baltimore: Johns Hopkins University Press.

Zerubavel, E. (2003). Time Map: Collective Memory and the Social Shape of the Past. Chicago: University of Chicago Press.

Zerubavel, Y. (1995). Recovered Roots: Collective Memory and the Making of Israeli National Tradition.Chicago: University of Chicago Press. 